\title{
Carnosinase deficiency
}

INSERM

\section{Source}

INSERM. (1999). Orphanet: an online rare disease and orphan drug data base.

Carnosinase deficiency. ORPHA:1361

Carnosinemia is a very rare inherited disorder that presents with serum carnosinase deficiency. 